\title{
Shear-hosted gold mineralization in the Oumé-Fettèkro greenstone belt, Côte d'Ivoire: the Bonikro deposit.
}

\author{
Zié Ouattara $^{1}$, Yacouba Coulibaly ${ }^{2}$, Marie-Christine Boiron ${ }^{3}$ \\ ${ }^{1}$ Université de Man, UFR des Sciences Géologiques et Minières, Département de Géologie et Matériaux, BP 20 Man, Côte \\ d'Tvoire. \\ ${ }^{2}$ Université Félix HOUPHOUËT-BOIGNY, UFR STRM, Laboratoire de Géologie du Socle et de Métallogénie, 22 BP 582 \\ Abidjan 22, Côte d'Ivoire. \\ ${ }^{3}$ Université de Lorraine, CNRS, GeoRessources, 54000, Nancy, France. \\ *Corresponding author: ziegbana@hotmail.fr
}

\begin{abstract}
The Bonikro deposit is the first in Côte d'Ivoire where gold is found within a sheared granodiorite, in the zones of boudins and faults. Gold is associated with scheelite and molybdenite in veins. The purpose of this paper is to highlight the characters of the shearing and the mineralized veins and to reveal the timing of their gold deposition in the Bonikro deposit. The investigation in this deposit and the observations of the drill cores have demonstrated the main role played by the shear zone and its three principal mineralized veins: sheeted veins, planar veins and transversal veins.

The deposit is dominated by a major structure: the Bonikro Shear Zone (BSZ) striking NorthSouth. The BSZ has affected the granitoid and as a consequence, it has produced two local shears striking NW and NE. The sheeted veins are earlier: thickness $(1 \mathrm{~cm})$ and sub-parallel sets of quartzo-feldspathic veins composed of milky quartz (70 to $80 \%$ ), albite (5-10\%) scheelite (up to 15\%) and pyrite (up to 5\%). They are the main host of the scheelite and also display the more visible gold in the deposit. The planar veins support the powellite and pyrite minerals. The transversal veins are late and composed of milky quartz (40\%), calcite (30\%), albite (10 $\%$ ), biotite (15\%), and sulfide (molybdenite up to $5 \%$ ). The molybdenite is the main sulfide. Each vein shows its typical minerals and resumes a generation of setting. These veins are bordered in the granodiorite by a corridor of a strong hydrothermal activity indicated by the sericitisation, the silicification, the chloritisation and the albitisation.

Gold is observed in both the granodiorite and in the basalt in the areas where these lithologies are sheared. It appears that the introduction of the auriferous mineralization at Bonikro postdates the magmatism and seems to be syn- to post-tectonic. This direct link between the structural features and the gold deposition has shown that the Bonikro deposit is a case of shearcontrolled gold mineralization.
\end{abstract}

Key words: Birimian gold, Bonikro deposit, Shear zone, Sheeted veins, Côte d'Ivoire. 


\section{Introduction and exploration context}

The West African Craton Paleoproterozoic formations are known as the world's premier Paleoproterozoic gold province (Goldfarb et al., 2017).

The search for, and the exploitation of, gold has brought to light the importance of the Birimian formations and its associated shear zones (Feybesse et al., 2006; Hein, 2010; Lompo et al., 2010, Baratoux et al., 2011). Gold is mostly found in the greenstone belts especially in the interface of the Birimian volcanic and volcanoclastics, and also in the contact between these formations and the plutonites, which interface and contacts are affected by the shear zones (Milési et al., 1989; Houssou, 2013; Houssou et al., 2017; Ouattara 2015; Ouattara et al., 2015; Ouattara et al., 2018a).

In Côte d'Ivoire, the Precambrian formations are dominated by seventeen greenstone belts (Fig. 1) which are aligned NE to ENE like their related shear zones (Yacé, 2002).

The Fettèkro is one of these greenstone belts and is likely the most productive gold belt in Côte d'Ivoire. In its southern part also called Oumé-Fettèkro greenstone belt, the extensive exploration has resulted to the discoveries of four gold deposits: Bonikro (15.9 kt at 1.8g/t), Agbahou, Dougbafla-Bandama and Hiré (Ouattara, 2015; Ouattara et al., 2015; Ouattara et al., 2018b; Houssou et al., 2017; Houssou, 2013; Ouattara et al., 2017; Gnanzou, 2006). These discoveries have shown that the Oumé-Hiré part of this greenstone belt is an effective goldproducing area also known as the Oumé-Hiré district.

The earlier exploration knowledge in this district has related to the Hiré auriferous quartz veins (Archambault, 1935; Chermette, 1935). In order to characterize these veins of Hiré, the above authors noted that the Birimian formations are intensely folded and locally, the metamorphism around the massifs reaches almost the amphibolite facies. From 1948 to 1956, the BUMIFOM (France overseas mining board) executed different activities including trenches, geophysics, soil geochemistry and drilling. This campaign helped to test and to nominate each of the five Hiré quartz veins. The reserves estimation of two of them, Agbalé and Akissi-so, gives 58000 $\mathrm{t}$ at $23.5 \mathrm{~g} / \mathrm{t}$ so around $1,360 \mathrm{~kg}$ of gold (Gnanzou, 2006). These investigations continued with the BRGM (office of geological and mining researches), from 1961 to 1962 with the geologist Berton then from 1966 to 1968 with Sonnendrucker as the principal geologist and brought to light that the Hiré area is well-endowed with gold resources.

Early in the 1990s, BHP Minerals undertook a geological mapping in its Hiré licence which produced a regional reconnaissance map (Houssou, 2013) that helps until today as a basis for exploration work in this area. In addition, BHP Minerals discovered the Agbahou gold deposit 
which licence has a common border with the Bonikro one. This map shows that the Bonikro area could be considered as a fold and Bonikro is settled on the right limb. Equigold in 1996 obtained the Oumé licence that was covering the Bonikro village. In its $1000 \mathrm{~km}$ square, the permit contains a contact oriented NNE between the lower and the upper Proterozoic formations.

The southern Fettèkro greenstone belt is known for the scarcity of its outcrops and its strong laterisation (Yacé, 1982, Ouattara et al., 2015). In consequence, the discovery of the Bonikro resulted from seven years of systematic exploration (Equigold, 2002).

The Bonikro first pit was located in the southern part of the deposit where the unique shear zone can be seen (Ouattara et al., 2018a). It appears through this study that the ore higher grades were found around the quartz veins striking towards $\mathrm{N}$ to NNE. It is the reason why the mine geologists were considering themselves as the workers around the "quartz veins".

In the second and main pit, the shear zone appears in the central part. The importance of these quartz veins and shear zones from Hiré to Bonikro was admitted (Gnanzou, 2006; Hanssen, 1992). Nevertheless, little was known about their characters and their control in the setting of the ore.

In this context, the discovery and then, the exploitation of gold in this southern Oumé-Fettèkro greenstone belts gave the opportunity to be more focused on the area (Hiré: Gnanzou, 2006; Agbahou: Houssou, 2013; Houssou et al., 2017; Bonikro: Ouattara, 2015, Ouattara et al., 2018a \&b; Dougbafla: Ouattara et al., 2017).

The main purpose of this paper is the understanding of the shear zone in the setting of the Bonikro deposit also the verification of the shear zone control in the mineralization.

\section{Methodology}

The methodology employed to study the Bonikro Shear zone and mineralized veins combines the fieldwork and the laboratories analyses. The fieldwork included mapping of the Bonikro open pit benches were undertaken to investigate the structural features and compared with core analyses in the mine's coreshed. This first step revealed the main shear zone and the mineralized veins, their field relationships, their primary mineral compositions and help to select representative samples. The utilization in the field of the mineralight lamp UVG-47 made it possible to detect the presence of the fluorescent minerals in the veins to differentiate between scheelite-bearing and non-scheelite bearing veins.

The second step gives the opportunity to determine the mineralogy of the samples from which 
55 thin sections of rock and ore were realized. The observations have been undertaken firstly on a polarizing microscope at the Laboratoire de Géologie du Socle et de Métallogénie (LGSM), University Félix HOUPHOUËT-BOIGNY, Côte d'Ivoire and also at the Laboratoire de Géoressources at the University of Lorraine, Nancy, France where an axiovision 4.7 was connected for picture capture. Secondarily, selected minerals were analysed on the SEM (JEOL JSM-7600F) and the EPM (Cameca SX100) at the Laboratoire de Géoressources, Nancy, France.

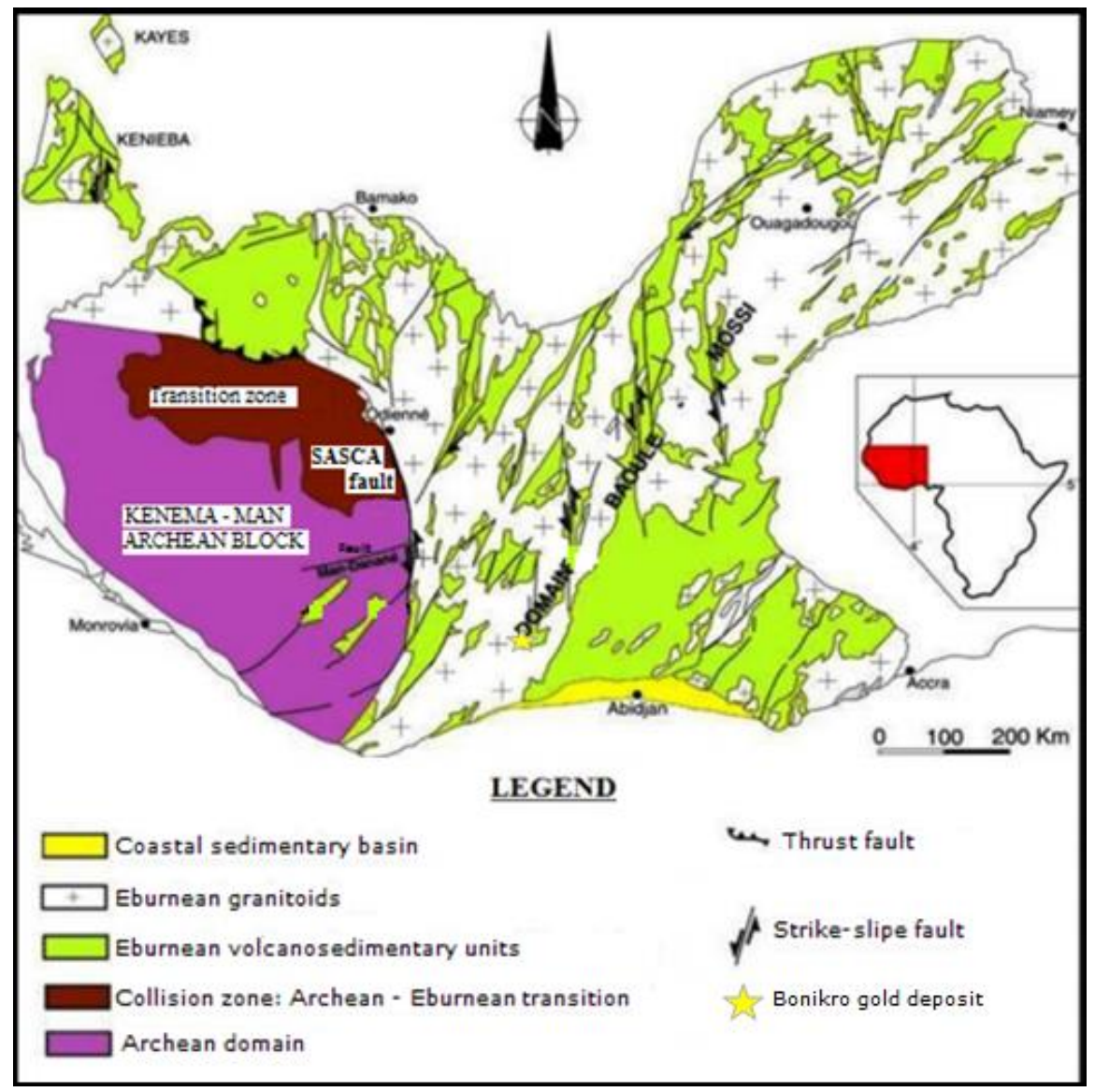

Figure 1 : Geological map of the West African craton (modified after Milési et al., 1989) showing the Bonikro gold deposit location. 


\section{Regional geology}

The outcrops are rare in the southern Fettèkro area, this is the reason why the main source of knowledge of its geology is based on that from the characterization of the auriferous gold veins of Hiré and later by the mineral exploration and exploitation form.

The Fettèkro greenstone belt as the sixteen others birimian volcano-sedimentary belts in Côte d'Ivoire strike NE-SW to NNE-SSW. These belts belong to the Proterozoic basement in the Baoulé-Mossi domain of the West African Craton (WAC) formed between 2.2 and $1.9 \mathrm{Ga}$ (Feybesse et al., 2006). This domain covers almost all the Côte d'Ivoire and is limited towards the West by the north-south trending Sassandra-Cavally fault (Fig.1).

The Fettèkro greenstone belt is one of the Precambrian larger belt in Côte d'Ivoire. Almost 300 $\mathrm{km}$ long and 40 to $5 \mathrm{~km}$ width extends from south of Dabakala (north of the belt) to Divo (south of the belt). Around the parallel $7^{\circ}$, it is divided in two parts. The Oumé-Hiré area represents the southern part of this belt (Yacé, 2002).

The supracrustal geology of this greenstone belt is made of schist and quartzite and also sandstone and conglomerates aligned NNE-SSW and affected by different injections of metabasites and metaacidites. (Yacé, 1982; Lemoine, 1988; Mortimer, 1990; Leake, 1992; Daouda, 1998; Houssou, 2013, Ouattara, 2015; Ouattara et al., 2015; Houssou et al., 2017).

The Birimian units of Hiré are composed of sedimentary and volcano-sedimentary formations (acid, neutral and basic metavolcanites, arkose, arkosic schist, conglomerates and associated sediments (Sonnendrucker, 1967). These formations are metamorphosed to the greenschist facies and intruded by massives granodiorites.

In favour of the discovery of the Agbahou gold deposit, Houssou et al. (2011) investigations revealed that two major lithological units are present i.e an easterly mafic to intermediate unit and a westerly volcano-sedimentary and associated sediments unit. These units are intercalated by the basic sills and cut by the acidic dykes.

The Bonikro gold deposit, $231 \mathrm{~km}$ in NW Abidjan, belongs to the Hiré town and formed contemporaneously with the gold deposits of Agbahou, Hiré and Dougbafla, the Oumé - Hiré gold district. 


\section{Geology of the Bonikro deposit}

The Bonikro deposit is geologically characterized by two units: a mafic volcanic unit in the eastern part and a volcano-sedimentary unit in the western part (Fig. 2). These primary two units are contemporaneous, then metamorphosed to the greenschist facies and intruded by the granodiorite (Ouattara et al., 2018a). The structural features of the deposit are dominated by a major structure: the Bonikro Shear Zone (BSZ) making the contact between the primary units. A diversity of faults, fractures, folds and veins is observed at Bonikro, revealing at least three phases of deformations (Ouattara, 2015).

The bedding $\left(\mathrm{S}_{0}\right)$ is observed within the sediments, in the western Bonikro region (Fig. 3a to 3e). They are striking $\mathrm{N} 090^{\circ}$ to $\mathrm{N} 170^{\circ}$ and showing different dips i.e towards east, north and south. These changes are due to the phases of deformation, folding that occurred before and after the granodioritic intrusion because the pluton is confined between bedded sedimentary units.

The $\mathrm{S}_{0}$ is clearly observed within the black shales where they are affected by a shortening phase that created the folds indicating the $\mathrm{S}_{1}$ (Fig. $3 \mathrm{a}$ to $3 \mathrm{~d}$ ). A second cleavage $\mathrm{S}_{2}$ is seen on the drill cores, cutting the $S_{0}$ and the $S_{1}$. The $S_{2}$ is a fracture cleavage and is mostly in the contacts zone between the primary lithologies and the intrusion.

A diversity of plicative structures is observed in the Bonikro pit and also through the drill cores (Fig. 3b, 4a \& 4b).

In the western side of the pit, numerous meso-folds are observed (Fig. $4 \mathrm{a} \& 4 \mathrm{~b}$ ). It is likely the quartz veins that have undergone a late phase of E-W compression giving right to the horizontal meso-folds. On drill cores, two types of microfolds are noticed. The first type is a folded vein of quartz, calcite and sulfides. The second type is an isocline intrafoliar and parallel to the foliation. These folds indicate that the main stresses were vertical. That can be related to the stresses rose from the setting of the granodiorite and those from the above primary lithologies. In the northern side of the pit, the strain-slips are encountered around the intrusion. Their impacts on the metabasalt have produced flakes as that of mylonites and on the metasediments, it has resulted on the blocks of different sizes (Fig. 4c \& 4d).

The structural features of the Bonikro gold deposit are made of the shear zone as the main structure and also minor structures comprising faults, fractures, boudins, veins and foliations.

The Bonikro Shear Zone (BSZ) is the major structure of the deposit (Fig. 2). It is globally oriented $\mathrm{N} 000^{\circ}$ to $\mathrm{N} 025^{\circ}$ and represents the first target to the gold mineralization in the zone where the granodiorite is absent. 


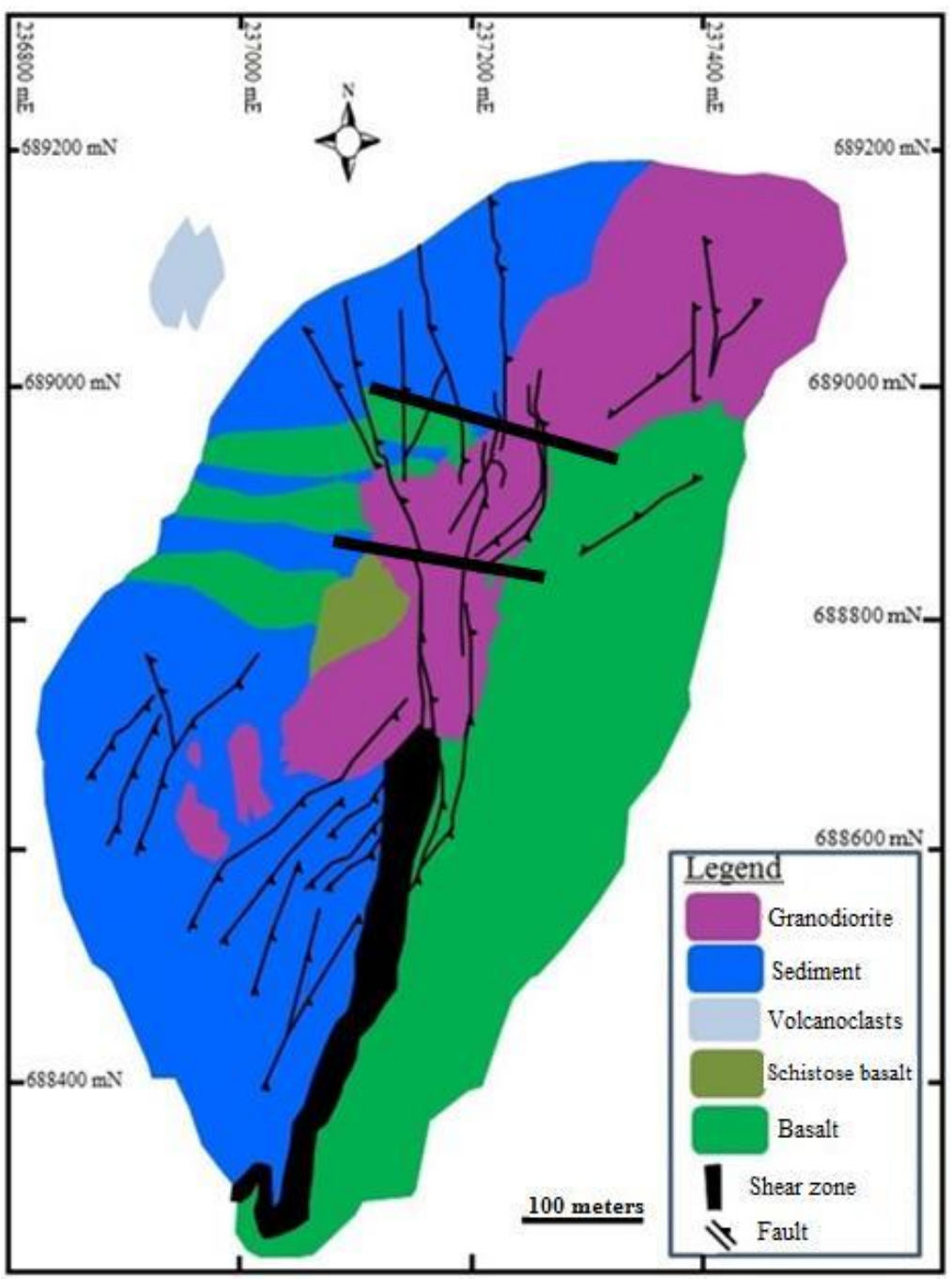

Figure 2: Geological map of the Bonikro gold deposit. 

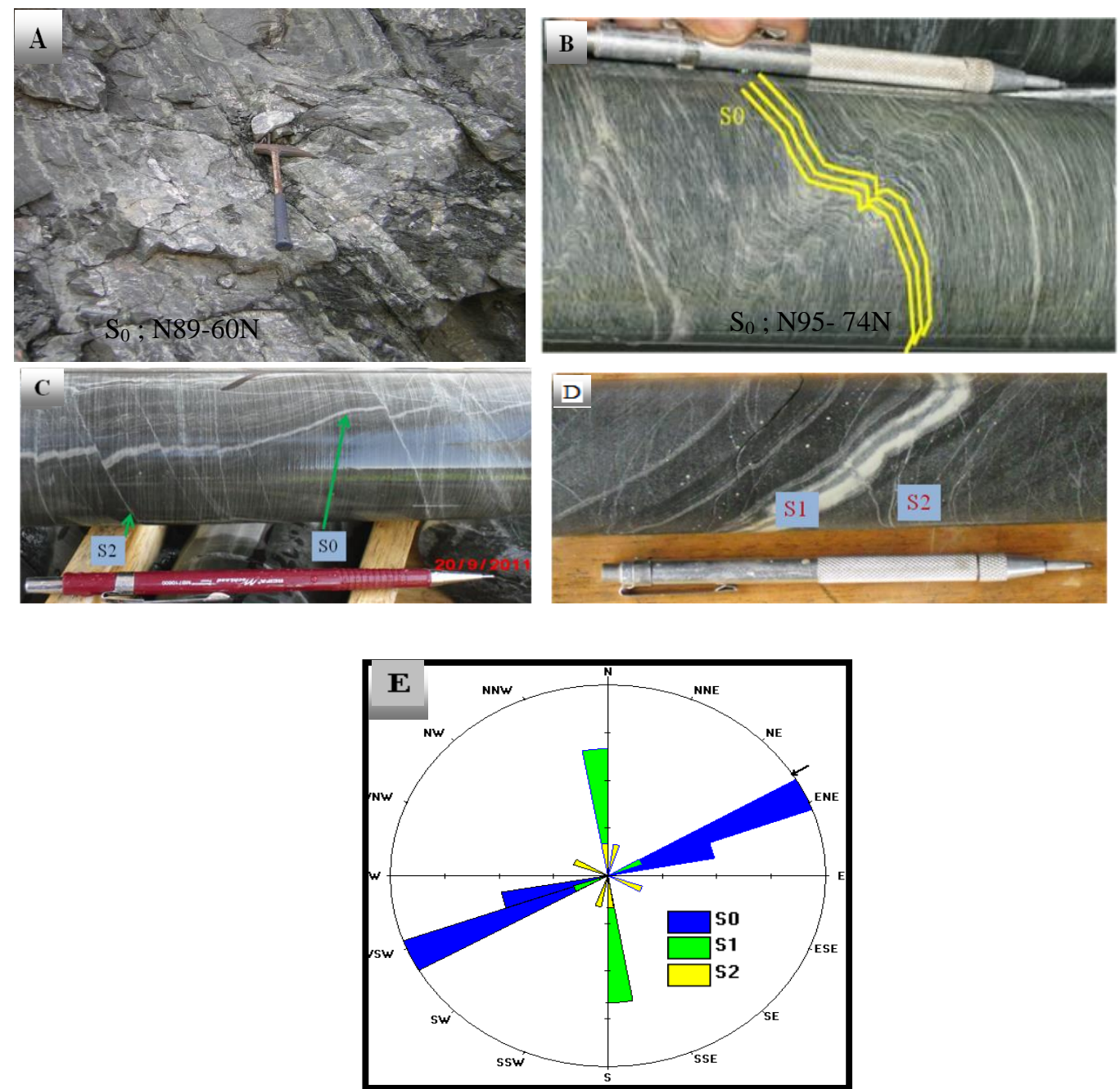

Figure 3: The folded bedding, the $S_{1}$ and $S_{2}$ and their orientation in the Bonikro gold deposit.

(a) $\mathrm{S}_{0}$ folded in the sediments, western Bonikro pit. (b) (c) and (d) $\mathrm{S}_{0}, \mathrm{~S}_{1}$ and $\mathrm{S}_{2}$ on the cores. (e) rose diagrams of $\mathrm{S}_{0}, \mathrm{~S}_{1}$ and $\mathrm{S}_{2}$. 

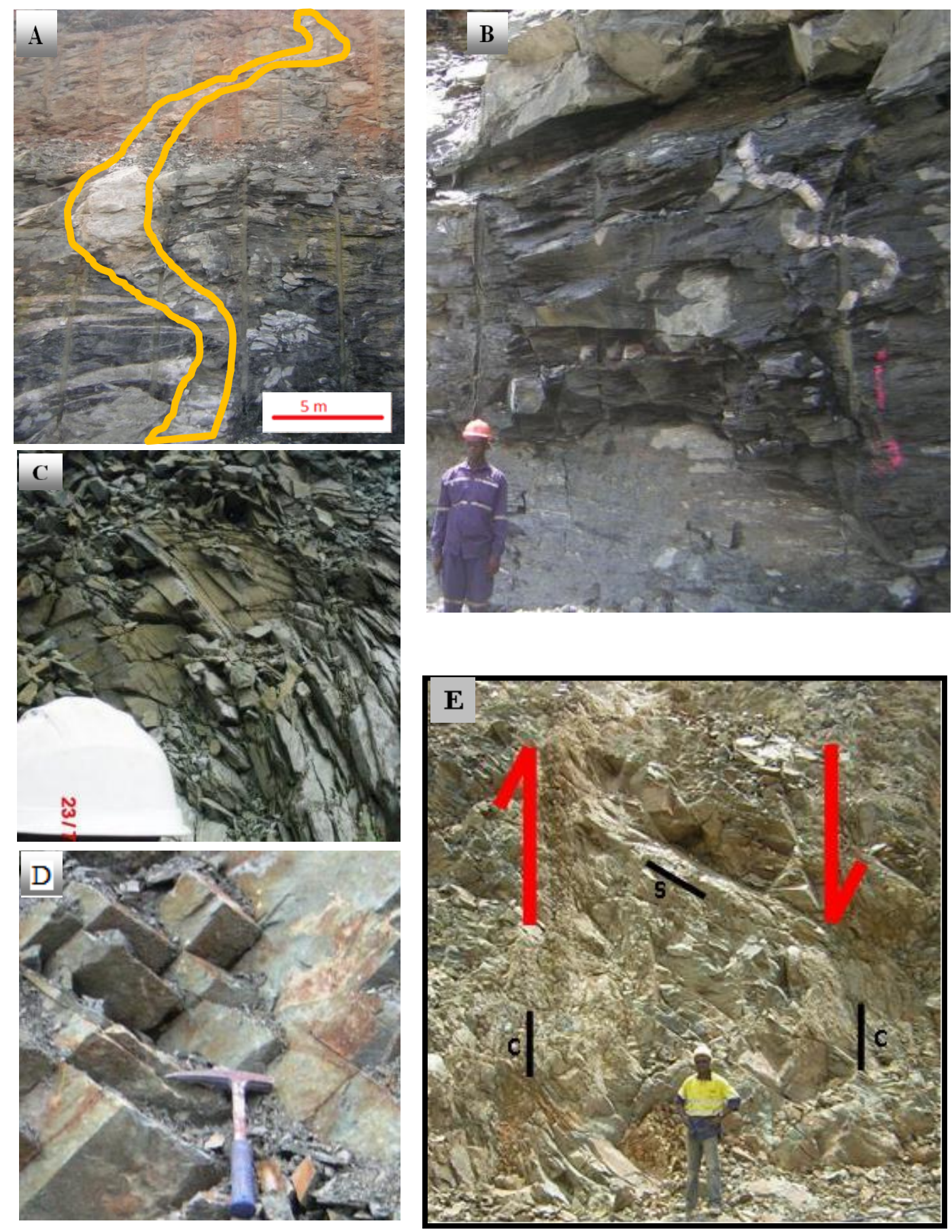

Figure 4: Macroscopic views of the folds, boudins and shearing in the Bonikro gold deposit.

A \& B: folded quartz veins in the western Bonikro pit

$\mathrm{C} \& \mathrm{D}$ : view of the flakes and blocks as a consequence of strain-slips

E: the S, C structures in the northern Bonikro pit 
In the south of the deposit, the BSZ strikes N000 to N015 and appears as a unique corridor making the contact between the two primary lithologies; the easterly mafic volcanics and the westerly volcanoclastics and sediments (Ouattara et al., 2018a).

In the heart of the deposit, the BSZ and the granodiorite make the interface of the aforementioned two lithologies. A part of the mafic volcanic is found as sheared basalt in the west, the pluton is also sheared by the BSZ which is divided into three structural domains striking respectively $\mathrm{N} 170^{\circ}, \mathrm{N} 000^{\circ}$ and $\mathrm{N} 025^{\circ}$.

In the north of the Bonikro pit (Fig. 4e), the BSZ three domains are shown even if the granodiorite is comprised between $\mathrm{N} 000$ to $\mathrm{N} 025^{\circ}$. The $\mathrm{N} 000^{\circ}$ domain is dipping towards the east when the $\mathrm{N} 025^{\circ}$ has a dip around NW. The $\mathrm{N} 170^{\circ}$ domain is hosted in the metasediments. We also notice that all along the BSZ, numerous fault and schistosity are created; the veins are mostly folded and boudinaged on both primary lithologies and the intrusive. In the metasediments, the dips are towards the north and the north-east, the $\mathrm{cm}$-scale boudins are associated with a normal fault. These orientations show that in the northern Bonikro, the shearing has raised the eastern side formations and those in the north and north-east are subsided. The granodiorite benches are plunging accordingly, a fault is linked with this plunge and makes the contact with the basalt. The related veins are made of milky or smoky quartz, showing different thickness ( 1 to $40 \mathrm{~m}$ ) and are associated with the gold. Because of their close relationship with the gold mineralization, this work is entirely based on all the sets of veins.

Two types of foliation are recorded at Bonikro. The first foliation is flux schistosity which presents two components. The first component is that produced before the crystallization of the granodiorite, known as the $S_{1}$. It is related to the effusive volcanism and those of the BSZ. The second component $\mathrm{S}_{2}$ is economically more important because it is associated with the granodiorite. The $\mathrm{S}_{2}$ has developed flakes on the primary lithologies, and is secant to the $\mathrm{S}_{1}$. The observation of the $S_{2}$ in core is mostly a footprint to detect a mineralized zone. This structure is easily recognizable by the strong sulphidation. The second foliation is a local fracture cleavage. It is observed in the north of the Bonikro pit along the contact of the sheared granodiorite and the schistose basalt.

Three families of faults F1, F2, and F3 (Fig. $2 \& 5$ a to 5c) are recognized and oriented respectively $\mathrm{N} 000^{\circ}$, $\mathrm{N} 064^{\circ}$ and $\mathrm{N} 174^{\circ}$. They shape the definitive orientations of the deposit. The F2 and F3 are affected the granodiorite and divided it into three domains: north, central and south. On drill cores, the F2 with a NW dip is bordering the granodiorite and control the base of this pluton. 

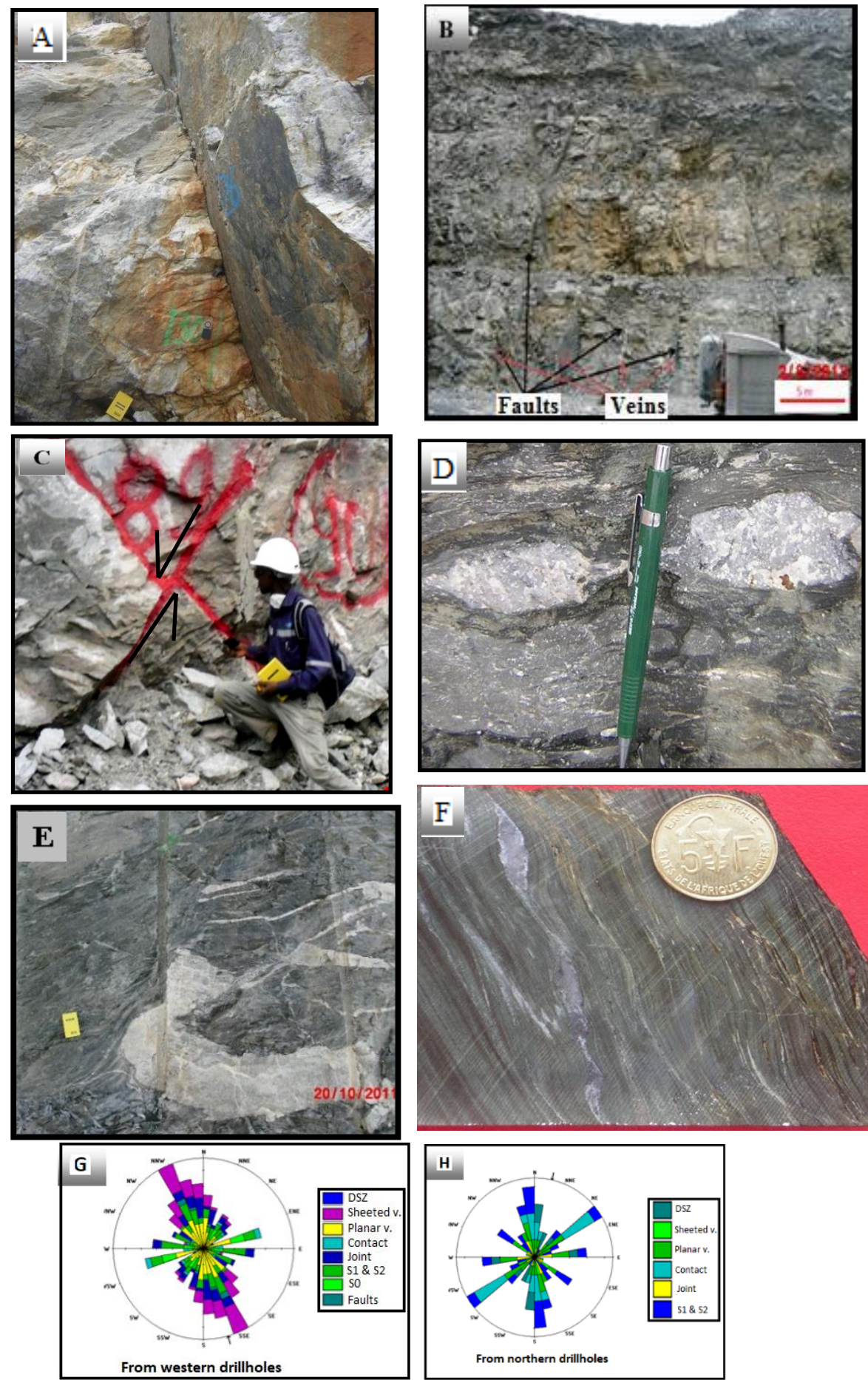

Figure 5: Description of the zones associated with the gold in the Bonikro deposit and the structures orientations.

A: Large molybdenite-bearing vein in the Bonikro

B \& C: Views of faults and veins on the pit benches

D \& E: Boudinaged quartz and granodiorite in the Bonikro pit

F: Sheared basalt showing the micro boudins of quartz on a drill core

G \& H: DSZ stands for ductile shear zone and V stands for Veins. 
In the south-west Bonikro, the granodiorite striking NNE falls on a dextral strike-slip fault which re-oriented a portion (150 to $200 \mathrm{~m}$ ) of this pluton towards NS, representing the central domain. From this central domain to the northern Bonikro pit, the granodiorite has been reoriented by a second dextral strike-slip fault. The molybdenite is widespread on theses faults, also with graphite and pyrites. These open faults have been filled by a milky to smokey quartz veins and their thickness can reach up to $40 \mathrm{~m}$.

A diversity of quartz veins is observed at Bonikro. Some of them are mineralized, others are not. These veins are related to the different tectonic history of Bonikro. In fact, the primary lithologies have been affected by intensive fracturation giving as a consequence the different faults and fractures. The fluids that circulated later left their content and produced these various veins.

Different boudins of centimetric to metric sizes are observed. They are perpendicular to the main compressive stresses and are sheared by the late sinistral thrust (Fig. $5 \mathrm{~d}$ to $5 \mathrm{f}$ ).

These boudins are associated with some changes; in the granodiorite, the phenocrysts of potassic feldspar and biotite are depleting when on the basalt, the dolomite is replacing the calcite in the foliation planes.

The distribution of these structures in the deposit is shown on the rose diagrams (Fig. $5 \mathrm{~g}$ $\& 5 h)$.

\section{Characteristics of the ore body}

The distribution of gold in the Bonikro deposit is along the BSZ, its related structures and the sheared lithologies. This observation of the mineralization from the southern to the northern parts of the pit has shown the importance and the control of the BSZ (Fig. $6 \&$ 7a to 7d).

In the southern domain, gold is found exclusively in the BSZ which made the contact between the two primary lithologies i.e the eastern volcanic and the western volcanoclastics and sediments. The mineralization is hosted in the N-S trending BSZ corridor dominated by the quartz and pyrite. 


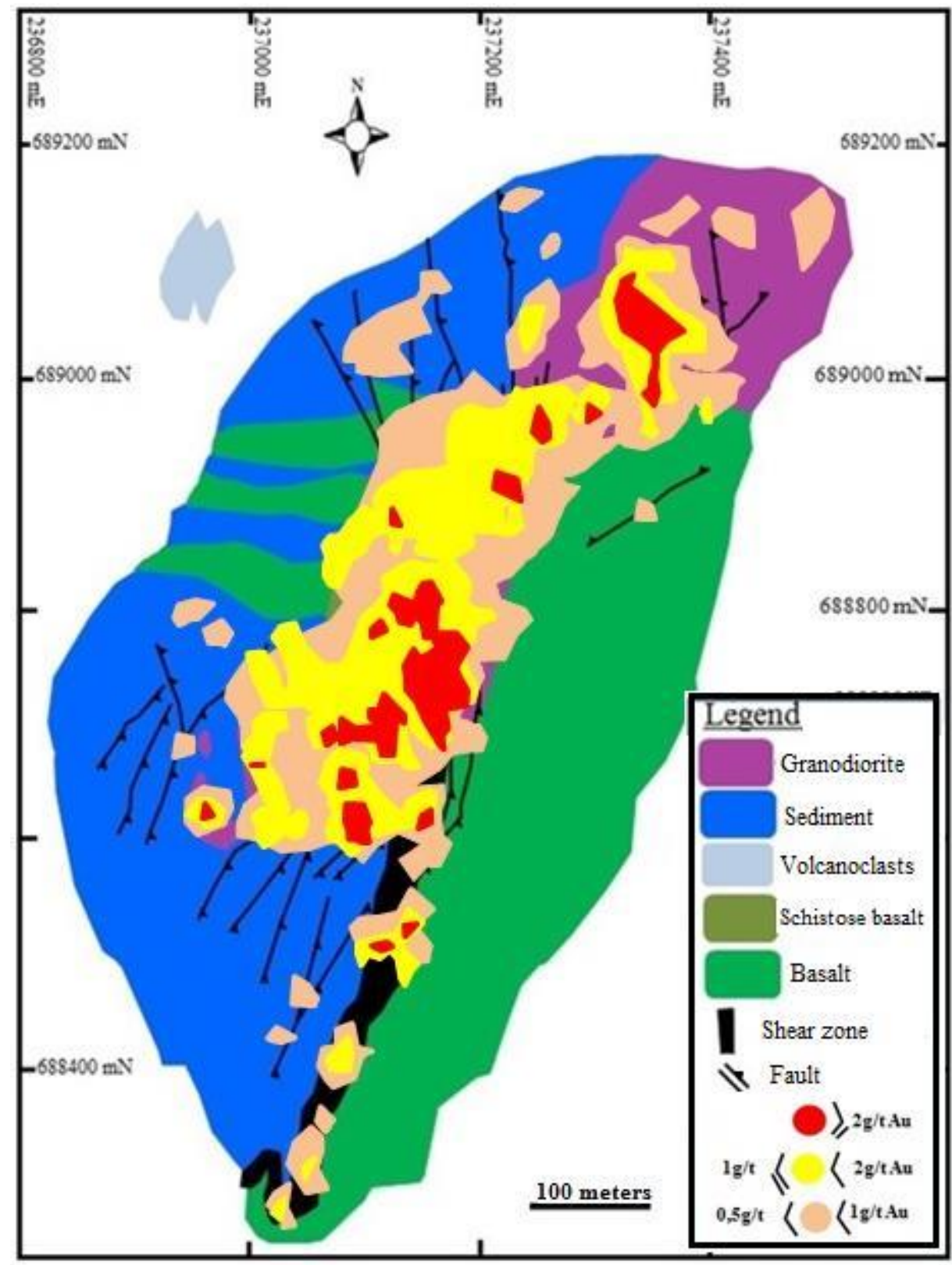

Figure 6 : Map showing the distribution of gold in the Bonikro gold deposit pit. 
In the central domain of the pit, gold is localized within the sheared lithologies firstly in the basalt and secondly in the granodiorite (Fig. $6 \& 7$ ). The mineralization lenses are associated with the BSZ related structures e.g the faults, veins and schistosity. The faults and fracture are striking N-S to NNE. The $\mathrm{S}_{2}$ is a key indicator of the mineralization in the sense that it made the contact between the pluton and the basalt. This $\mathrm{S}_{2}$ is recognisable by its abundant pyrite and admit that the gold enrichment is post-magmatic and syn- to post-tectonic.

The ore grade increases with the intensity of the shearing in the basalt. Towards this increase, calcite is replaced successively by dolomite and ankerite in the areas where pyrite and pyrrhotite are abundant. In consequence, the higher ore grade is found in intensely sheared zones.

In the granodiorite, the zones of shearing are the higher ore grade zones also. The shearing is shown by the deformed megacrystals of feldspar and biotite and the presence of three mineralized quartz veins showing a particular relation with the Bonikro gold mineralization. Also through the investigation on the cores, these veins control most of the deposit visible gold. According to their setting chronology, they are named: sheeted veins, transversal veins and planar veins.

The sheeted veins are the oldest at Bonikro (Fig. 7e). They consist in a sub-parallel set of almost $1 \mathrm{~cm}$ thick quartzo-feldspathic veins composed of milky quartz (70 to $80 \%)$, albite (5-10\%) scheelite (up to $15 \%$ ) and pyrite (up to $5 \%$ ). At the microscopic scale, the quartz is observed in the center of the veins whereas the albite is observed in the veins halos. In their setting, they cut the megacrystals of potassic feldspar showing absolutely that they are formed after the magmatism events. These veins are the main host for scheelite and also most of the visible gold.

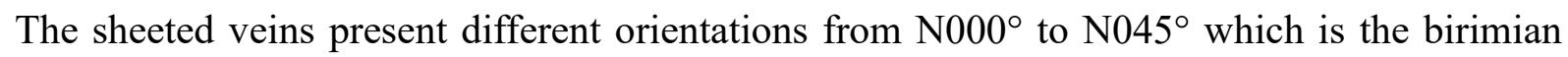
direction with the dips of $50^{\circ}$ towards east but also, N135 to $\mathrm{N} 190^{\circ}$ dipping towards $\mathrm{E}$.

The planar veins are the second mineralized veins at Bonikro because of their relation with the sheeted veins (Fig. $7 \mathrm{~b}$ to $7 \mathrm{e}$ ). They are veins of 1 to $3 \mathrm{~cm}$ wide and comprise quartz associated with powellite and pyrite. At the microscopic scale, pyrite is fractured showing the shearing influence in their setting. These veins are oriented between $\mathrm{N}_{009^{\circ}}$ and $\mathrm{N} 018^{\circ}$ with a shallow to moderate dip (20 to $\left.35^{\circ}\right)$ towards E.

The transversal veins are the youngest and consist of larger quartz veins cutting the two previous mineralized and composed of: milky quartz (40\%), calcite (30\%), albite (10\%), biotite (15 $\%$ ), and sulfides (molybdenite up to $5 \%$ ). The transversal veins are perpendicular to the sheeted veins, present mostly a thickness of 0.5 to $1 \mathrm{~cm}$ strike $\mathrm{N} 120^{\circ}$ to $150^{\circ}$ and are dipping 40 to $60^{\circ} \mathrm{E}$ (Fig. 7d).

These veins carried the molybdenite and can reach $40 \mathrm{~m}$. At the microscopic scale, the 

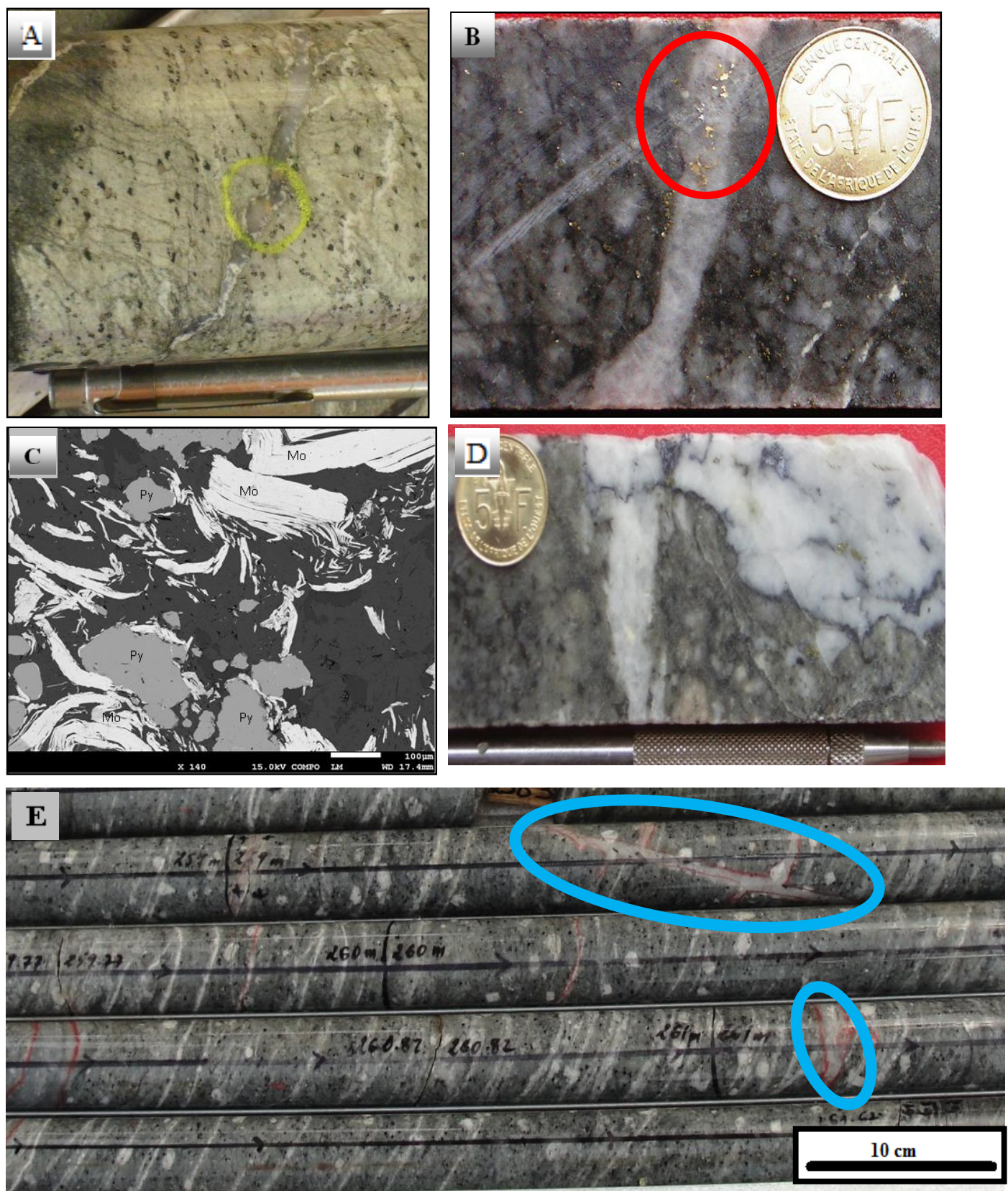

Figure 7: The localisation of gold and its associated molybdenite and pyrite within the veins in the Bonikro deposit.

A: A drill core of a sheared basalt with visible gold and a quartz vein surrounded by the disseminated pyrites. B: A planar vein with visible gold

C \& D: microscopic and macroscopic views of sheared vein of quartz + pyrite + molybdenite.

E: A tray of the granodiorite showing the relation between the sheeted and planar veins

Mo: molybdenite and Py: pyrite 
molybdenite is sheared and unevenly distributed around the broken pyrites in the zones where the transversal veins cut the planar or the sheeted veins (Fig. 7c \& 7d).

In the northern Bonikro, the mineralization is correlated with the three domains of the BSZ. The first controlling the contact between the sediments and the granodiorite, is oriented NW. The second N-S is in the granodiorite. And finally the third, representing the interface between the pluton and the basalt is striking NE. These change of orientation of the granodiorite and the contacts between the intrusive and the primary lithologies have help to control the circulation of the fluids and the deposition of gold. The strain-slips are also present in the pit northern part. They are from the stress resulted from the setting of the intrusion and the effects of two fracturation. As a result, the strain-slip show some flakes.

\section{Discussion}

\section{A regional shear zone}

The main lithologies of the Bonikro gold deposit are the mafic volcanic in the east and volcanosedimentary and sediments in the west. The interface of these two primary lithologies is occupied by the BSZ (Ouattara et al., 2018a). From the south to the north of the Bonikro pit, this interface strikes from $\mathrm{N}_{000^{\circ}}$ to $\mathrm{N} 025^{\circ}$, from the meridian to the Birimian direction (Fig. 2).

The Bonikro gold deposit is defined by the shearing in the BSZ. The second order important features are: the bedding which strike varies from $\mathrm{N} 045^{\circ}$ to $\mathrm{N} 090^{\circ}$ or $\mathrm{N} 135^{\circ}$ with different dips, the faults and fractures striking $\mathrm{N} 000^{\circ}, \mathrm{N} 064^{\circ}$ and $\mathrm{N} 174^{\circ}$, the $\mathrm{S}_{2}$ that is associated with the intrusion of the pluton, the centimetric to metric boudins, the sheeted veins oriented NE to SW and dipping towards E, and the transversal veins are striking NW.

The BSZ and associated faults and fractures are regional. The Agbahou gold deposit presents these same features and orientations, it is called the Agbahou Tectonic Zone, ATZ (Houssou, 2013, Houssou et al., 2017). It appears that the BSZ and the ATZ are parts of the same goldrich regional shear zone that can be found also in the Hiré deposits. The Bobosso prospect in the northern part of this Fettèkro greenstone belt is also influenced by the shear zone of birimian orientation (NE) as its quartz veins (Gnanzou, 2014). Before the discovering of these gold deposits and prospect, according to Yacé (1982) and Olson (1989), the brittle and ductile structural elements found in the Fettèkro greenstone belt were linkable to a phase of unique progressive deformation event of 2.1 billion years.

The Angovia and Aféma gold deposits located in other greenstones belts in Côte d'Ivoire show also that they are associated with a similar shear zone (Coulibaly et al., 2008; Assié, 2008). In 
Ghana, the Ashanti shear zones presents the same orientations of that of Bonikro, trending NE to NNE (Oberthür et al., 1997, Wille and Klemd, 2004; Feybesse et al., 2006).

\section{A shear-controlled gold mineralization}

The gold mineralization in the Bonikro deposit is largely controlled by the structural features expressed as the BSZ and its second orders structures i.e faults, foliation, fractures, veins, boudins, folds...

Gold is found within three main quartz-scheelite, quartz-powellite and quartz-molybdenite veins (Ouattara et al., 2018b). This positive correlation with the gold mineralization helped to identify the sheeted veins, the planar and the transversal veins. These veins show that gold in Bonikro has been introduced after the magmatism clearly syn- to post-tectonic. The evolution of their content from scheelite to powellite and finally to molybdenite is an evidence of the setting of each of these mineralized veins at different periods but much more important they were able to control the different introduction of the mineralized fluids (Fig. 8). This timing of gold deposition in Bonikro is rather similar to those described in the Agbahou deposit (Houssou et al., 2017), Angovia (Coulibaly et al., 2008), Aféma (Assié, 2008).

It appears that the BSZ and the ATZ are parts of the same gold-rich regional shear zone that can be found also in the Hiré deposits. The Bobosso prospect in the northern part of this Fettèkro greenstone belt is also influenced by the shear zone of birimian orientation (NE) as its quartz veins (Gnanzou, 2014). The importance of the shear zone in the greenstone belts (Hein, 2010; Baratoux et al., 2011) and the NW trending faults found in the Bonikro deposit are well known in other parts of West Africa (Milési et al., 1989; Feybesse et al., 2006; Lompo, 2010). For Feybesse et al. (2006), the Ashanti NW faults control the distribution of the mineralizing fluids. The mineralization at Bonikro can be found in all of the lithologies i.e the basalt, the sediment and the granodiorite in the zones where they are sheared. This distribution of the mineralization through the lithologies is the proof that the structural context has played an enormous control on the gold deposition.

In the Julie deposit in Ghana, Salvi et al. (2015) have noticed the influence of the shearing in the setting of this gold deposit, most of their veins were boudinaged. The deposits of Julie and of Bonikro have many similarities in terms of their shear zones, veins and sheared intrusive in the heart of the mineralization. 


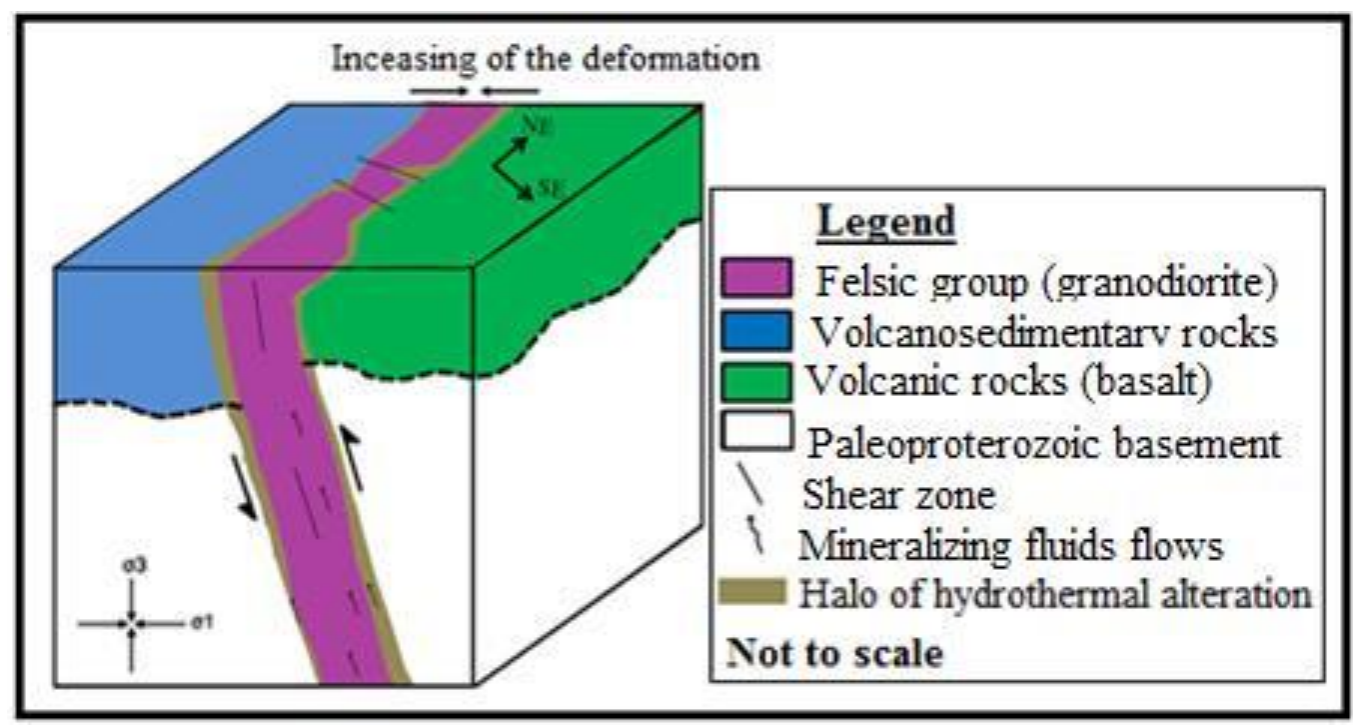

Figure 8 : Modelling the Bonikro shear zone in the setting of the Bonikro gold deposit.

\section{Conclusion}

The Bonikro gold deposit is located in the southern Oumé-Féttèkro greenstone belt, also known as the Oumé-Hiré gold district. The deposit is hosted by a sheared granodiorite and in a network of three mineralized quartz veins named as sheeted, planar and transversal veins supporting respectively the minerals of scheelite, powellite and molybdenite associated with gold.

The main shear zone occupying the interface between the primary lithologies is striking N-S to NE. It has later been divided into three shear zones oriented NW, NS and NE. The shear zone served as the pathways of the mineralizing fluids this is why the sheared basalt, sediment and granodiorite contain the ore.

Two dextral thrust are noticeable in the deposit showing as a consequence the southern, centre and northern part of the deposit.

The structural history of the Bonikro gold deposit is summarized in three points: (i) the regional plicative event that set up the regional grain of NE trending, (ii) the setting of the regional shear zone locally termed BSZ that redirected primary faults and (iii) the formation of secondary structures: dextral thrust veins that reactivated the shear faults and fractures and control the circulation of the mineralizing fluids. 


\section{Acknowledgements}

The authors wish to thank their warm gratitude to the Newcrest Mining Limited for its supports in the realization of this work. Also, the authors thank the leaders of the IGCP638 project and the reviewers, whose patience and contributions have improved the manuscript. 


\section{References}

Archambault J. (1935). Rapport sur les gisements aurifères. Régions : Divo, Dabou, Dimbokro, Abidjan, Bouaflé (CI). Notes complémentaires, Mission 1934-1935, Gouv. gén. A.O.F., Insp. gén. des T.P., Serv. des Mines, Dakar, 3 p.

Assié K. E. (2008). Lode gold mineralization in the Paleoproterozoic (Birimian) volcanosedimentary sequence of Afema gold district, southeastern Côte d'Ivoire. Thesis, Faculty of Energy and Economic Sciences. Technical University of Clausthal, Germany, 198 p.

Baratoux L., Metelka V., Naba S., Jessell M.W., Gregoire M. and Ganne J. (2011). Juvenile paleoproterozoic crust evolution during the Eburnean Orogeny (2.2-2.0 Ga), western Burkina Faso. Precambrian research, 191, pp. 18-45.

Chermette A. (1935). Les filons de quartz aurifère de Hiré (Côte d'Ivoire). Rapport $\mathrm{n}^{\circ} 200$, Gouv. Gén. De l’A.O.F., Insp. gén. des P.T., Serv. des Mines, Dakar, 15 p.

Coulibaly Y., Boiron M.C., Cathelineau M. and Kouamelan A.N. (2008). Fluid immiscibility and gold deposition in the birimian quartz veins of the Angovia gold deposit (Yaouré, Ivory Coast). Journal of African Earth Sciences, 50, pp. 234-254.

Coulibaly Y., Kouamelan A.N., Djro C.S., Pothin K.B.K. et Boffoue M.O. (2008). Les altérations associées à la minéralisation aurifère d'Angovia (Massif du Yaouré, centre de la Côte d'Ivoire), Rev. Ivoir. Sci. Techno., 11, pp. 159-175.

Daouda Y.B. (1998). Lithostratigraphie et pétrologie des formations birimiennes de ToumodiFettêkro (Côte d'Ivoire) : implication pour l'évolution crustale du Paléoprotérozoïque du Craton ouest africain. Thèse. Université d'Orléans - Géosciences, Mémoire n737, 191 p.

Equigold N.L. (2002). Traditional gold in Oumé, rapport interne. 30 p.

Feybesse J.L., Billa, M., Guerrot C., Duguey E., Lescuyer, J.L., Milési J.-P. and Bouchot, V., (2006). The paleaoproterozoic Ghanaian province: geodynamic model and ore controls, including regional stress modeling. Precambrian Research 149, pp. 149-196.

Goldfarb R., André-Mayer A., Jowitt S. and Mudd, G. (2017). West Africa: The world's premier Paleoproterozoic gold province. Economic Geology, vol. 112, no. 1, pp. 123-143.

Gnanzou A. (2006). Etude lithostratigraphique de la région de Hiré dans le centre-sud de la Côte d'Ivoire (Permis de recherche PRA 37) : implication à la connaissance de la minéralisation aurifère. DEA, UFR STRM, Univ. Cocody, 60 p.

Gnanzou A. (2014). Etude des séries volcano-sédimentaires de la région de Dabakala (NordEst de la Côte d'Ivoire) : genèse et évolution magmatique. Contribution à la connaissance de la minéralisation aurifère de Bobosso dans la série de la Haute-Comoé. Thèse de Doctorat, Univ. Paris Sud Orsay, France et Univ. Félix Houphouët-Boigny, 303 p.

Hanssen E. (1992). The agbaou deposit, final report. BHP Minerals Côte d'Ivoire, Archives SODEMI, $26 \mathrm{p}$. 
Hein K.A.A. (2010). Succession of structural events in the Goren greenstone belt (Burkina Faso): implications for West African Tectonics. Journal of African Earth Sciences, 56, pp. 8394.

Houssou N. N. (2013). Etude pétrologique, structurale et métallogénique du gisement aurifère d'Agbahou, Divo, Côte d'Ivoire. Doctorat, Univ. Félix Houphouët-Boigny, 177p.

Houssou N. N., Allialy M. E., Kouadio F. J. L-H. and Gnanzou A. (2017). Structural control of auriferous mineralisation in the Birimian: case of the Agbahou deposit in the region of Divo, Côte d'Ivoire. International Journal of Geoscience 8, pp. $189-204$.

Houssou N. N., Coulibaly Y. et Tourigny G. (2011). Etude lithostructurale du gisement aurifère d'Agbahou (région de Divo, Côte d'Ivoire). Journal Africain de communication scientifique et technologique 11, pp. $1393-1407$.

Leake M.H. (1992). The petrogenesis and structural evolution of the early Proterozoic Fettekro greenstone belt, Dabakala region, NE Côte d'Ivoire, Ph.D Thesis, University of Portsmouth, U.K., 315 p.

Lemoine S. (1988). Evolution géologique de la région de Dabakala (Nord-Est de la Côte d'Ivoire) au Protérozoïque Inférieur, Unpubl. D. Sc. thesis, Univ. Clermont-Ferrand, France, $388 \mathrm{p}$.

Lompo M. (2010). Structural evolution of the paleoproterozoic belts (Eburnean event) in the Man-Leo shield, West Africa Craton. Key structures for vertical to transcurrent tectonics. Journal of African Earth Sciences, 58, pp. 19-36.

Milési J.P., Feybesse J.L., Lédru P., Dommanget A., Ouédraogo M.F., Marcoux E., Prost A., Vinchon C., Sylvain J.P., Johan V., Tégyey M., Calvez J.Y., Lagny P. (1989). Les minéralisations aurifères de l'Afrique de l'Ouest, leurs relations avec l'évolution lithostructurale du protérozoïque inférieur. Chron. Rech. Min., Fr. 497, pp. 3-98.

Mortimer J. (1990). Evolution of Early Proterozoïc Toumodi volcanic group and associated rocks, Ivory coast. PhD Thesis, Portsmouth polytechnic, U.K., 244 p.

Oberthür T., Weiser T. and Amanor J.A. (1997) - Mineralogical setting and distribution of gold in quartz veins and sulphide ores of the Ashanti mine and other deposits in the Ashanti belt of Ghana: genetic implications. Mineralium Deposita 32, pp. 2-15.

Olson S.F. (1989). Carte géologique de la concession de Hiré. BHP Minerals, Archives, SODEMI, $1 \mathrm{p}$.

Ouattara A.S., Coulibaly Y. et Kouadio F.JL.H. (2017). Les altérations hydrothermales associées à la minéralisation aurifère du gisement de Dougbafla (district d'Oumé-Hiré, centreouest de la Côte d'Ivoire). European Scientific Journal, Vol. 13 N³0, pp. 108-125.

Ouattara Z. (2015). Caractères lithostratigraphique, structural, géochimique et métallogénique du gisement d'or de Bonikro, sillon birimien de Fèttékro, centre-sud de la Côte d'Ivoire. Doctorat, Univ. Félix Houphouët-Boigny, 275 p.

Ouattara Z., Coulibaly Y. and Lieben F. (2015). Pétrographie du gisement d'or de Bonikro, sillon birimien d'Oumé-Féttèkro, Côte d'Ivoire. European Scientific Journal, vol. 11, N²1, 
pp. 119-132.

Ouattara Z., Coulibaly Y. and Boiron M.C. (2018a). Lithostratigraphy of the Bonikro gold deposit: contribution to the setting of the birimian units in the southern Fettèkro greenstone belt, Cote d'Ivoire. Rev. Ramres, Vol.06, N01, pp. 6-14.

Ouattara Z., Coulibaly Y. et Boiron M.C. (2018b). Apport des minéraux d'altération dans la caractérisation du gisement d'or de Bonikro, sillon birimien de Fettèkro, Côte d'Ivoire. Afrique Science, 14 (06), pp. 343-358.

Sonnendrucker P. (1967). Etude de synthèse sur l'or en Côte d'Ivoire. La région aurifère du pays Dida, rapport n²00, SODEMI, 1967, 75 p.

Salvi S., Amponsah P.O., Siebenaller.L., Béziat D., Baratoux L., Jessell M. (2015). Shearrelated gold mineralization in northwest Ghana: the Julie deposit. Ore Geol. Rev.

DOI: 10.1016/j.oregeorev.2015.08.008

Wille S.E. and Klemd R. (2004). Fluid inclusion studies of the Abawso gold prospect, near the Ashanti belt, Ghana. Mineralium Deposita, 39, pp. $31-45$.

Yacé I. (1982). Etude géologique du volcanisme éburnéen dans les parties centrale et méridionale de la chaîne précambrienne de Fettèkro. Ministère des mines, République de Côte d'Ivoire. 156 p.

Yacé I. (2002). Initiation à la géologie. L'exemple de la Côte d'Ivoire et de l'Afrique de l'Ouest. Edition CEDA, Abidjan, Côte d'Ivoire, 183 p. 